\title{
The Development of Aperture at Residential Buildings in Mediterranean Climates for Mitigation of Carbon Emissions
}

\author{
Dr. Maryam Iranfar ${ }^{1}$, Dr. Salar Salah Muhy Al-Din,"* \\ ${ }^{1}$ Independent Researcher, Kyrenia- Northern Cyprus, Turkey \\ ${ }^{2}$ Department of Architecture, Girne American University, Kyrenia- Northern Cyprus, Turkey
}

Received March 5, 2021; Revised July 28, 2021; Accepted October 20, 2021

\section{Cite This Paper in the following Citation Styles}

(a): [1] Dr. Maryam Iranfar, Dr. Salar Salah Muhy Al-Din, "The Development of Aperture at Residential Buildings in Mediterranean Climates for Mitigation of Carbon Emissions," Civil Engineering and Architecture, Vol. 9, No. 7, pp. 2452 - 2463, 2021. DOI: 10.13189/cea.2021.090730.

(b): Dr. Maryam Iranfar, Dr. Salar Salah Muhy Al-Din (2021). The Development of Aperture at Residential Buildings in Mediterranean Climates for Mitigation of Carbon Emissions. Civil Engineering and Architecture, 9(7), 2452 - 2463. DOI: 10.13189/cea.2021.090730.

Copyright $\odot 2021$ by authors, all rights reserved. Authors agree that this article remains permanently open access under the terms of the Creative Commons Attribution License 4.0 International License

\begin{abstract}
The study aims to enhance the efficiency of the design process in the early stages of the design through guidance on the aperture design of buildings in Mediterranean regions. The study focuses on the outer glazing areas as the weakest part of the envelope for thermal resistance. Simulation software 'Design Builder' has been applied to assess $\mathrm{CO}_{2}$ emission in the residential buildings in Kyrenia through their apertures, and the ways to reduce carbon dioxide emission. Therefore, an eventual model has been developed and simulated according to the initial data obtained from the selected building samples as case studies. The study has concluded with mathematical models to assess the relationship between the size of apertures and the emission of carbon dioxide in the various topographical regions of Kyrenia concerning the sea and mountain views. The study would provide academic legislators and local authorities with new ideas in Kyrenia and Northern Cyprus.
\end{abstract}

Keywords Aperture, Carbon Dioxide Emission in Buildings, Window to Wall Ratio, 'Design Builder' Software, Kyrenia- Northern Cyprus

\section{Introduction}

Global warming is a significant threat for the communities and settlements which are located beside the coastal areas in the world because each $10 \mathrm{~cm}$ rise in sea level will immerse $10 \mathrm{~m}^{2}$ strips of the coastal area around the world (Nunez, 2019). Carbon dioxide emissions from buildings increase because of the direct use of fossil fuels or through electricity which generates from fossil fuels [1]. Thermal comfort performance takes the biggest part of energy consumption in residential buildings [2,3], and consequently increase $\mathrm{CO}_{2}$ emission from building sectors. Therefore, improving energy consumption retrofit in the buildings has a significant role in mitigation of carbon dioxide emission, and slow down the short-term climatic change [4]. The building sector consumes more than $40 \%$ of the global energy and produces $24 \%$ of the greenhouse gases (GHG) [5]. If climatic change adaptation strategies are well-regarded, then reducing building emissions must be a major task [5]. A good design can significantly reduce the amount of energy used in a building and thus reduce carbon and GHG emission, by considering orientation, location and natural light and wind [6]. It should be mentioned that technology and creativity in design play a key role in building low-emission architecture [7]. Affecting energy efficiency with minimal energy requirements and reducing carbon dioxide emissions from the building can be achieved by proper aperture element design at an early stage [8]. The apertures are the weakest points in resistance of the building against heat gain and 
loss. Heat gains or losses are expressed by heat flow via aperture, which is dependent on the temperature difference between in or out of the building. It should be mentioned that the amount of heat gained from incident solar radiation is determined by the indication angle, as well as the amount of heat lost due to leakage through cracks. A small percentage of conduction losses is due to air leakage, which is $1-5 \%$ in normal windows and higher in thermally optimized windows, and reaches $3-9 \%$ in thermally efficient windows [9]. The current study tries to reduce the carbon dioxide emission in residential buildings in Kyrenia-North Cyprus. This is through understanding the effect of 'the aperture' physical characteristics (glazing area and material properties) on the energy consumption. 'Aperture' is defined in this study as a transparent opening (outer glazing area). They are also important as architectural elements to adding an aesthetic value to the building design. The development of the specific part of the envelope as aperture could be easier than the development of whole the envelope with several elements as (roof, basement, and external walls). Kyrenia in Northern Cyprus has selected as a region for this study for two reasons. Firstly, for its unique topographic character which includes settlements on the coastal area, inner- lands, and mountains area. Secondly, it encourages a subjective issue, where the surrounding nature let the occupants to interact with the surrounded nature and prefer the sea view and the mountain's view, as distinguished view in the region of the study. The pleasure derived from the view is intimately connected to the contents of the view. According to Christoffersen (1999) as cited in [10], the natural views like mountains, rivers, and green lands, are more satisfying than man-made views like buildings and car parks. Further, people who lived on the top floors of the selected sample buildings were more satisfied than those who lived on the lower floors. Accordingly, the importance of the aperture emerged in the current study. The study raises the following questions: (i) how much the aperture physical characteristics in the residential buildings of Mediterranean climates affect building $\mathrm{CO}_{2}$ emissions according to the limitation of the current study? And what are the suggestions to mitigate this effect? (ii) How appropriate would it be to develop a model for calculating $\mathrm{CO}_{2}$ emissions dependent on resizing glazing elements or the window-to-wall ratio (WWR) to regulate emissions in residential buildings with excellent views in Kyrenia, Northern Cyprus? Furthermore, the study hypothesizes that understanding the relationship between the physical characteristics of outer glazing areas, could develop the architectural environmental design criteria in Mediterranean climates. Therefore, the aim of the study is to find developed guideline for aperture physical characteristics for lower carbon dioxide emission in the buildings, which assist the professionals and government bodies to legislate new building rules.

\section{Theoretical Framework}

\subsection{Aperture in Architecture}

Guattari [11] considers the house to be a box in which three ecological paradigms reside: environmental ecologies, psychological ecologies, and socio-cultural ecologies. As a result, the house environment is that which distinguishes the internal and external ecologies, and it is often opaque. Accordingly, apertures are important interfaces between the outside and the inside, allowing optical access from the inside to the outside and opposite. Commonly, the occupants prefer the access to natural light more than artificial light. In addition, aperture would provide view, outside weather inspection, and air ventilation, [12,13]. Moreover, according to Heerwagen [14], aperture has four essential advantages: outside condition observation, a sense of connection to the outside atmosphere, renewal function, and curing capacity. Givoni [15] addresses that windows are key factors in passive solar strategies. It should be mentioned that since the windows are the weakest insulated feature in envelope of the building, they also are net losers of inside winter heating and gainers of outside heating in the summer, even in the good passive design buildings with a top-quality glazed window. As a result, the design of windows in a building is affected by a combination of factors. There is no constant plan or approach for developing the best passive solar design. Much will be determined by place of the building, land height, environment, and construction site, as well as the amount of light needed in the building [16].

\subsection{The Effects of Building Aperture on Energy Consumption and Carbon emission}

Carbon dioxide emissions in the world are increasing and estimated in 2017 by 37 billion metric tons [17], and in 2021 increase more. According to Lucon, and Ürge-Vorsatz [18], most of GHG emissions are indirect carbon dioxide emissions from the usage of electricity in buildings. In other sides, the aperture causes $20 \%$ of the heat loss/gain in single- story buildings, and 30\% of that in the multi- story buildings [19]. Moreover, the California Energy Commission speculates that solar radiation gains via windows responsible for about $40 \%$ of cooling demand in a typical building [20]. Regulating the amount of solar radiation that enters a building is important for achieving indoor comfort and, more broadly, better energy retrofit. In the winter, solar heat penetration through windows will help minimize space heating energy usage. Excessive solar radiation passing through the glass during the summer, particularly in warmer areas and countries with a Mediterranean climate, can cause overheating of the indoor environment, resulting in high air conditioning use [21]. National building codes should be established and enforced in those countries to limit energy use for air conditioning 
during the summer. Furthermore, requiring the installation of sun shading systems or windows with a Solar Heat Gain Coefficient (SHGC) of less than or equal to 0.5 will help to reduce the incoming energy flow [20]. Between summer and winter, the amount of solar radiation falling on the buildings are different. Different types of research $[6,20,22,23]$ have shown that solar radiation has a negative effect on buildings energy consumption during the long sunny days of summer in warm climates. However, solar radiation could have positive effect on energy efficiency in buildings in winter because of moderate midday rates of solar radiation from clear sky. According to a study conducted in Cyprus [24], the interior temperature varies between $10-20^{\circ} \mathrm{C}$ during the winter months and $30-50^{\circ} \mathrm{C}$ during the summer months when no active system was being used. The study showed the effect of solar radiation on the inner temperature inside Cypriot buildings. Window placement, shading, and glazing materials all have a significant impact on visual comfort [25], and a window with good designed provides a visual pleasure. Low Heat Transfer Coefficient value (U-value) for the window can enhance thermal comfort through maintaining the interior air temperature on the glass surface temperatures relatively. In hot and arid climates, east-west windows and unshaded south windows could also cause additional cooling loads in the northern side of the globe [20]. The heat that flows via an aperture is a combined process in which it follows three principles: radiation, convection, and conduction [10]. The solar ray is electromagnetic spectrum and is divided into wavelength intervals, a portion of solar radiation is "visible" and provides indoor natural lighting and illumination [26]. Thermophysical properties of glazing materials play an important role in limiting energy consumption in buildings. Low-emittance (low-e) coatings, also known as efficient energy glazing, which are spectrally optional coatings designed to improve energy efficiency via transparent openings [27]. According to Ding et al., [28], adding an additional layer of glass in the aperture is less effective than adding a layer of insulation.
The current study tries to investigate the effect of glass materials on carbon dioxide emission in the buildings in Kyrenia through the dominated used glass in the study area based on samples of case study buildings.

\section{Methodology}

This study is developed based on the case study methodology. The case study includes the selection of thirty existing residential buildings in Kyrenia with various typologies such as detached and semi-detached houses and apartment blocks. The case studies are limited to the city of Kyrenia, as a Mediterranean city, which has different topographic characteristics, and can be categorized to the following areas: coastal, inn land, and mountainous areas. The selected buildings are only limited to the residential buildings. The selected buildings are limited to the first three floors to neutralize additional factors that can be involved with the increase of height like wind speed. Moreover, the study concerns to the buildings with two main orientations: Northern orientation (sea view), and Southern orientation (Mountain View). Furthermore, the direct observation is the method to collect data, which includes:

a) Classify the types and materials of the apertures (glazing area and frames) for the existing buildings in (coastal, Inner-land and Mountain's settlement) of Kyrenia, as seen in Table ' 1 '.

b) Determining the WWR in the residential buildings in Kyrenia.

c) Identifying types the building envelopes for the selected case studies, including the existing non-transparent elements for the envelope (roofs, outer walls, and floors). In addition to the area of the case studies with the aid of 'Cad' files if it is available to formulate the area of the eventual model in the simulation software. 
Table 1. Distribution of window types in case study buildings. (Developed by Researchers)

\begin{tabular}{|c|c|c|}
\hline No. of Case study building & Type of Window & Sample \\
\hline $\begin{array}{c}1,2,3,10,14,15,16,17,18,19,20,21,22, \\
23,24,25,26,27,28,29,30\end{array}$ & $\begin{array}{l}\text { Plastic Processing (having } 2 \text { compartments), Double } \\
\text { Glassed Window (Uncoated Glass), } 6 \mathrm{~mm}\end{array}$ & \\
\hline $4,8,9,11,12$ & $\begin{array}{l}\text { Aluminum Processing } \\
\text { Double Glass uncoated Window, } 6 \mathrm{~mm}\end{array}$ & \\
\hline 5 & $\begin{array}{l}\text { Plastic Processing (Having } 2 \text { Compartments), Single } \\
\text { Glassed Window with } 4 \mathrm{~mm} \text { thickness }\end{array}$ & \\
\hline 6 & $\begin{array}{l}\text { Aluminum Processing, Single Glassed window with } \\
66 \mathrm{~mm} \text { thickness }\end{array}$ & \\
\hline 7,13 & $\begin{array}{l}\text { Wooden Processing, Single Glassed window with } \\
\qquad 6 \mathrm{~mm} \text { thickness }\end{array}$ & \\
\hline
\end{tabular}

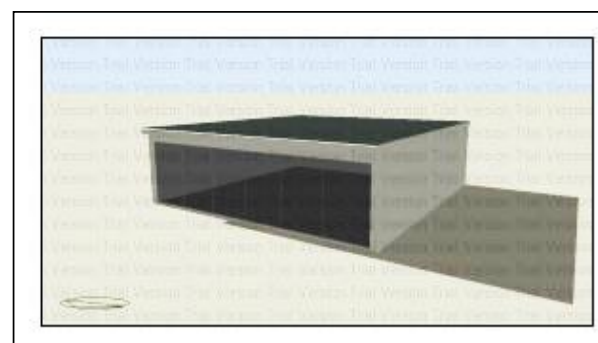

Morning

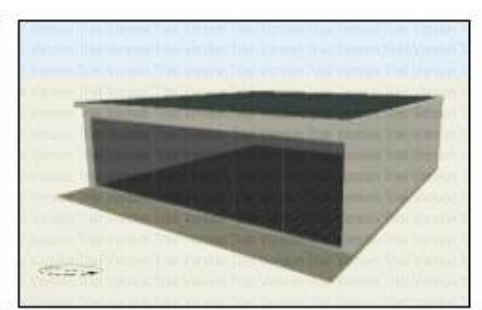

Noon

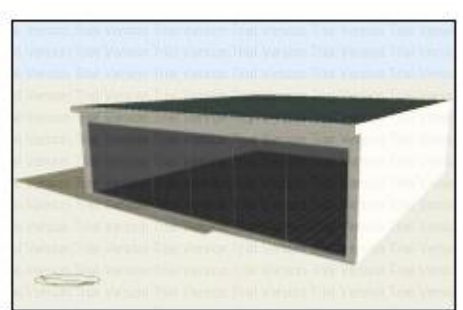

Afternoon

Figure 1. Eventual model for the study (in summer, the morning, noon, and afternoon times). (Design Builder software)

The main objective of a building performance simulation model is to define the building performance aspects that are relevant to building design, construction, and operation. Therefore, the models were developed based on existing data collected during the different fieldwork from the selected case studies. The attained data from the field work was considered as initial indicator. The aim of the modelling is to simulate real conditions according to initial indications. The climate condition of the case studies is simulated in the Design Builder.

Design Builder is perhaps the most detailed program for working with the graphic interface of the (Energy plus) thermal simulation engine. A 3D model is created using the graphical interface. The program assesses energy efficiency of the 3D model, [29]. It is used as a supplemental material in Environmental Systems
Integration courses and coursework that use energy audit at different universities [30].

A single-family unit is designed without basement. Floor dimensions $10 \times 10$ meters. The unit geometry consists of a simple cubic shape, and can be considered analogous to the selected case study units in study area with the limits of the current study, as seen in figure ' 1 '.

The location data was manually entered into database of the program, since the name Kyrenia was not present in database of the program.

1. Location Tab: On the Location tab, the location tab includes the following data about the location: location, location details, time zone, weather simulation, wind speed, and direction. The Site tab also includes the following information about the site: Latitude, Longitude and Height of the site. By the aid of google 
earth online program the average elevation of the selected sites located in the Kyrenia region is determined as follows: coastal areas (10 meters), inner- lands (60 meters), and mountainous sites (300 meters). Weather information for Kyrenia containing average monthly temperatures was manually entered into the program's database. The required were collected from metrological sites for the weather data of Kyrenia. The next important tab is the Building Model Data tab. The required data must be entered manually in the aforementioned tab. The Building Model Data tab would be accessed on the following ribbons: Activity, Building, Openings, Lighting, Conditioning, Options, and CFDs.

2. Activity Tab: In this paper, the study followed the DB default program data regarding occupancy intensity and type of activity. For householding intensity (20\%) and for activity ( 1 met for male, 0.85 met for female, 0.75 met for children). Because it fits the current study. In the same situation, occupants' winter clothing is (1.00 Clo.), and summer clothing is (0.5 Clo.).

3. Construction Tab: Building materials can be selected in the "Construction" tab. DB uses building components to model heat conduction across roofs, walls, floors, and other opaque parts of the envelope. The construction materials were selected based on the direct observation of the selected case study buildings and the aid of plans and available 'Cad' files.

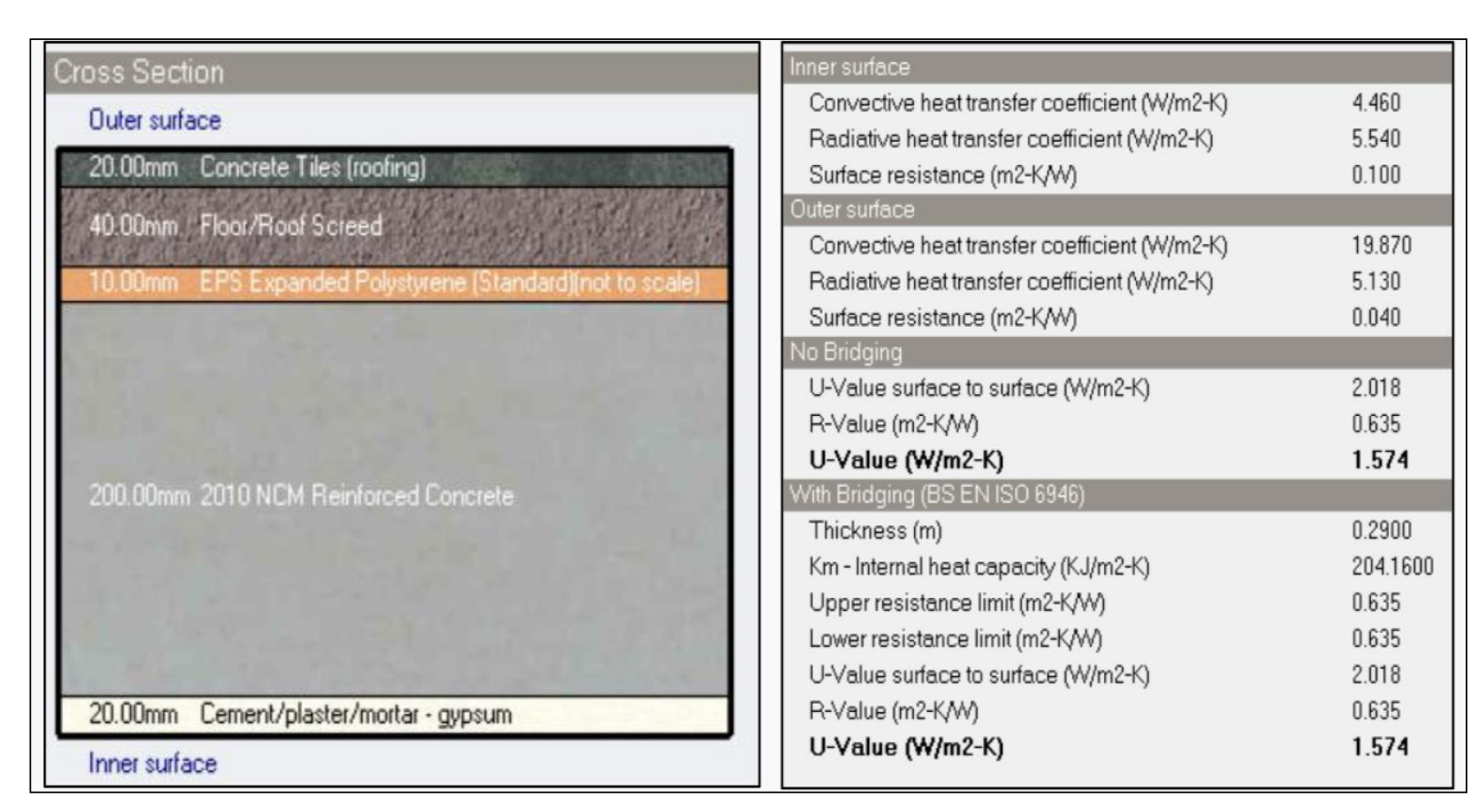

Figure 2. U- Value for applied material layers of flat roofs construction in Kyrenia. (Design Builder software). a) Roof: The construction materials used in building flat roofs are: The Expanded Polystyrene (EPS) insulation layer with $10 \mathrm{~mm}$ thickness that is placed on top of a concrete layer. On the top of this layer cement screed layer with $40 \mathrm{~mm}$ thickness is added. Both of these two layers are laid on a $200 \mathrm{~mm}$ concrete slab. Upper than the screed cement layer is the final external layer which is $20 \mathrm{~mm}$ concrete tiles. The inner surface of the concrete slab from inside of building is covered with $20 \mathrm{~mm}$ gypsum plaster. See Figure '2'.

b) External walls: The selection of exterior wall materials is based on direct observation of the 30 case study samples in the Kyrenia region. The proposed and specific external walls of the simulated model contain the following details: 25 $\mathrm{mm}$ of cement plaster on the outside, $200 \mathrm{~mm}$ of masonry concrete blocks, covered with $25 \mathrm{~mm}$ of gypsum plaster on the inside. The last inner surface is $1 \mathrm{~mm}$ acrylic paint.

c) Floor: The materials used for floor construction are: A typical floor is wrapped with ceramic tiles (10 $\mathrm{mm})$. Under the ceramic tiles a layer of cement mortar (30 mm thick) is laid. Below the insulating layer, there is a $70 \mathrm{~mm}$ medium weight concrete layer. The last layer is a layer of compacted soil with a thickness of $250 \mathrm{~mm}$. 
4. Opening Tab: The opening tab in DB software identifies all the glass elements of the building. The program identifies five types of openings: windows, sub-roofs, eyelets, doors and vents. This study focuses on glass windows and doors.

Three different WWR have been applied in this study to investigate the relationship between the glazing size and the energy consumption which leads to carbon dioxide emission in typical residential buildings of Kyrenia.

The mentioned types of WWR are:

(1) Standard WWR: Refers to WWR recommended based on regional and international standards based on climate and wall orientation. According to Lapithis [21], the WWR for south facing walls is $31 \%$ and for north oriented walls $17 \%$;

(2) Average WWR: It is based on average WWR of selected thirty case study buildings in Kyrenia, depending on the wall orientation;

(3) Maximum WWR: Indicates the size of glass in selected case study units that have built over the past decade in Kyrenia. Furthermore, the WWR are applied in two orientations based on the limit of the current study which are south (mountains view), and north (sea view), as illustrated in Table '2'.
Table 1. The dimensions of glazing areas and WWR facing either sea or mountain's view. (Developed by researcher)

\begin{tabular}{|c|c|c|c|}
\hline WWR Value & \multirow[b]{2}{*}{$\begin{array}{l}\text { Maximum } \\
\text { WWR } \\
\text { (Window to } \\
\text { Wall Ratio) }\end{array}$} & \multirow[b]{2}{*}{$\begin{array}{c}\text { Average } \\
\text { WWR } \\
\text { (Window to } \\
\text { Wall Ratio) }\end{array}$} & \multirow[b]{2}{*}{$\begin{array}{c}\text { Standard } \\
\text { WWR } \\
\text { (Window to } \\
\text { Wall Ratio) }\end{array}$} \\
\hline $\begin{array}{l}\text { Dimension of } \\
\text { the glazing } \\
\text { area on the } \\
\text { wall(m) }\end{array}$ & & & \\
\hline \multirow{2}{*}{$\begin{array}{c}\text { North } \\
\text { direction (Sea } \\
\text { View) } \\
\end{array}$} & $78 \%$ & $41 \%$ & $17 \%$ \\
\hline & $9.48 * 2.46$ & $5.59 * 2.20$ & $2.32 * 2.20$ \\
\hline \multirow{2}{*}{$\begin{array}{c}\text { South } \\
\text { direction } \\
\text { (Mountain } \\
\text { View) }\end{array}$} & $70 \%$ & $32 \%$ & $31 \%$ \\
\hline & $9.48 * 2.21$ & $4.36 * 2.20$ & $4.22 * 2.20$ \\
\hline
\end{tabular}

According to direct observations, three types of windows have been used in selected case study buildings in the Kyrenia region. Therefore, the three recorded types of windows $(3 \mathrm{~mm} / 6 \mathrm{~mm}$ double transparent glass, $3 \mathrm{~mm} /$ $6 \mathrm{~mm}$ double grey air and $3 \mathrm{~mm} / 6 \mathrm{~mm}$ air clear triple glass) were applied in the simulation model in order to compare the final simulation results and know the amount of loss Heat through the windows in both sea and mountain views.

Figure ' 3 ' shows the types of glass and the U-value for the applied window frames as employed in DB software.

\begin{tabular}{|c|c|c|c|c|c|}
\hline \multicolumn{2}{|l|}{ Data Report (Not Editable) } & \multicolumn{2}{|l|}{ Data Report (Not Editable) } & \multicolumn{2}{|l|}{ Data Report (Not Editable) } \\
\hline General & & General & & General & \\
\hline Dbl Clr $3 \mathrm{~mm} / 6 \mathrm{~mm}$ Air & & Dbl Grey $3 \mathrm{~mm} / 6 \mathrm{~mm}$ Air & & Trp Clr $3 \mathrm{~mm} / 6 \mathrm{~mm}$ Air & \\
\hline Source & EnergyPlus da & Source & EnergyPlus da & Source & EnergyPlus do \\
\hline Category & Double & Category & Double & Category & Triple \\
\hline apeginn & & Categury & & Region & General \\
\hline 枹Region & General & Region & General & Colour & \\
\hline & & & & Definition method & \\
\hline Definition method & & Definition method & & Definition method & 1-Material laye \\
\hline Definition method & 1-Material laye & Definition method & 1-Material laye & Layers & \\
\hline Layers & & Layers & & Number layers & 3 \\
\hline Number layers & 2 & Number layers & 2 & Outermost pane & \\
\hline Outermost pane & & Outermost pane & & $\square$ Pane type & Generic CLEA \\
\hline$\square$ Pane type & Generic CLEA & $\square$ Pane type & Generic GREY & $\begin{array}{l}\text { Flip layer } \\
\text { Window gas } 1\end{array}$ & \\
\hline Flip layer & No & Flip layer & No & r. Window gas type & AIR $6 \mathrm{MM}$ \\
\hline Window gas 1 & & Window gas 1 & & Pane 2 & \\
\hline T. Window gas type & AIR $6 \mathrm{MM}$ & (1) Window gas type & AIR 6MM & $\square$ Pane type & Generic QLEA \\
\hline Innermost pane & & Innermost pane & & Flip layer & No \\
\hline$\square$ Pane type & Generic CLEA & $\square$ Pane type & Generic CLEA & Window gas 2 & \\
\hline Flip layer & No & Flip layer & No & (r) Window gas type & AIR $6 \mathrm{MM}$ \\
\hline Outside Surface & & Outside Surface & & PPane type & Generic CLEA \\
\hline Fix convective heat trans... & No & Fix convective heat trans... & No & Flip layer & No \\
\hline Inside Surface & & Inside Surface & & Outside Surface & \\
\hline Fix convective heat trans... & No & Fix convective heat trans... & No & Fix convective heat trans... & No \\
\hline Calculated Values & & Calculated Values & & Inside Surface & \\
\hline Total solar transmission ... & 0.762 & Total solar transmission ... & 0.615 & Fix convective heat trans... & No \\
\hline Direct solar transmission & 0.705 & Direct solar transmission & 0.526 & Calculated Values & \\
\hline Light transmission & 0.812 & Light transmission & 0.551 & Total solar transmission .... & 0.682 \\
\hline U-value (ISO 10292/EN... & 3.226 & U-value (ISO 10292/EN ... & 3.226 & Direct solar transmission & 0.595 \\
\hline U-Value $(\mathrm{W} / \mathrm{m} 2-\mathrm{K})$ & 3.159 & U-Value $(\mathrm{W} / \mathrm{m} 2-\mathrm{K})$ & 3.159 & Light transmission & 0.738 \\
\hline Apply enhanced surface ... & No & Apply enhanced surface ... & No & U-Value $(W / m 2-K)$ & 2.178 \\
\hline Cost & & Cost & & Apply enhanced surface ... & No \\
\hline Cost per area (USD/m2) & 233.709 & Cost per area (USD/m2) & 249.290 & Cost & \\
\hline Radiance Daylighting & & Radiance Daylighting & & Cost per area (USD/m2) & 264.871 \\
\hline Diffusing & No & Diffusing & No & Radiance Daylighting & \\
\hline
\end{tabular}

Figure 3. Selected window types thermal properties (direct solar transmission, light transmission, and U-value) in DB software. (Design Builder software) 
Table 2. Overhead lighting for various lighting configurations [29]

\begin{tabular}{|c|c|c|c|c|c|}
\hline Data & 1-Suspended & 2-Surface Mount & 3-Recessed & $\begin{array}{c}\text { 4-Luminous } \\
\text { Recessed Celling }\end{array}$ & $\begin{array}{c}\text { 5-Retur-Air } \\
\text { Ducted }\end{array}$ \\
\hline Return Air Fraction & 0.0 & 0.0 & 0.0 & 0.0 & 0.54 \\
\hline Radiant Fraction & 0.42 & 0.72 & 0.37 & 0.37 & 0.18 \\
\hline Visible Fraction & 0.18 & 0.18 & 0.18 & 0.18 & 0.18 \\
\hline Convected Fraction & 0.40 & 0.10 & 0.45 & 0.45 & 0.10 \\
\hline
\end{tabular}

According to the various field observation, the researcher observed that the majority of the frames for windows in case study buildings were made of Polyvinyl chloride (UPVC). Therefore, UPVC material was chosen for the window frames in the simulated models.

5. Lighting Tab: Based on the direct observation made inside the selected case study buildings, LED lighting template below was chosen for the simulation. The Luminaire type specified for the simulation was based on the Surface Mount column in Table 3.

According to the selected type of lighting from Table ' 3 ', the radiant fraction was 0.720 , visible fraction was 0.180 , and convective fraction was 0.10 .

6. HVAC Tab: The HVAC model within the DB software defines all the details and specifications of the HVAC system. Based on direct observations made within the selected case study buildings, the AC system was selected for the proposed model. When all the required data has been entered in the different tabs, the model is simulated. The different WWR value, site topography, and building orientation (north and south) were taken into account during the simulation process.

\section{Analysis and Findings}

In this paper, the electricity consumption is considered as a major factor for estimating $\mathrm{CO}_{2}$ emissions in the selected building samples. The main reason for considering electricity as a major factor is to avoid complication during the calculation process. It should also be noted that the plurality of the case study buildings uses active heating and cooling systems to heat and cool their units. Passive heating and cooling systems are used less frequently in case study buildings. By looking at electricity as a key factor in assessing the amount of energy consumption and $\mathrm{CO}_{2}$ emissions in the selected case study buildings, a pragmatic evaluation can be done.

\subsection{Coastal Area}

Carbon dioxide emission was calculated through energy consumption using DB's simulated model for both north and south oriented buildings. The findings of the simulated model that are modified for the coastal region addressed the following points: Sea-viewed (north) buildings that use the maximum WWR have largest annual carbon emissions compared to the standard and standard and average WWR in the buildings. Also, the simulated results illustrate the correlation between glass size, energy consumption and $\mathrm{CO}_{2}$ emissions in the simulated model. According to the simulation results, the following point can be proposed and implemented: To reduce energy consumption and consequently mitigate carbon dioxide emissions in the building, triple clear glass would be selected. It should be mentioned that when WWR is the maximum, triple clear glass is the most suitable type compared to single glazing and double glazing, the same is true for standard and average WWR. The reported results showed that a building in a coastal area that has sea view with a standard WWR produce lower carbon dioxide than a building in a similar location with a maximum and even average WWR. Buildings placed in this area overlooking the mountains are producing more $\mathrm{CO}_{2}$ compared to the buildings facing the sea. $\mathrm{CO}_{2}$ emission with maximum WWR is higher than the emission in other WWR values. The difference in $\mathrm{CO}_{2}$ emission between buildings of average WWR and buildings with WWR standards is commonly negligible and insignificant. Triple Clear $3 \mathrm{~mm} / 6 \mathrm{~mm}$ Air is the best for this view and Double Grey $3 \mathrm{~mm} / 6 \mathrm{~mm}$ Air coming in the second stage while, Double clear $3 \mathrm{~mm} / 6 \mathrm{~mm}$ Air coming third, as what has found in sea view of this region. See Table ' 4 '. 
Table 3. Annual Carbon dioxide emission in coastal area (sea and mountains views) with different WWR and Glass material, through DB simulation (Developed by researchers)

\begin{tabular}{|c|c|c|c|c|c|c|c|}
\hline \multicolumn{7}{|c|}{ North (Sea View) } & \multicolumn{3}{c|}{ South (Mountains View) } \\
\hline \multicolumn{2}{|c|}{ Coastal } & $\begin{array}{c}\text { Double clear } \\
3 \mathrm{~mm} / 6 \mathrm{~mm} \\
\text { Air glass }\end{array}$ & $\begin{array}{c}\text { Double Grey } \\
3 \mathrm{~mm} / 6 \mathrm{~mm} \text { Air } \\
\text { glass }\end{array}$ & $\begin{array}{c}\text { Triple Clear } \\
3 \mathrm{~mm} / 6 \mathrm{~mm} \\
\text { Air glass }\end{array}$ & $\begin{array}{c}\text { Double clear } \\
3 \mathrm{~mm} / 6 \mathrm{~mm} \text { Air } \\
\text { glass }\end{array}$ & $\begin{array}{c}\text { Double Grey } \\
3 \mathrm{~mm} / 6 \mathrm{~mm} \text { Air } \\
\text { glass }\end{array}$ & $\begin{array}{c}\text { Triple Clear } \\
3 \mathrm{~mm} / 6 \mathrm{~mm} \\
\text { Air glass }\end{array}$ \\
\hline $\begin{array}{c}\text { Max. } \\
\text { WWR }\end{array}$ & $\begin{array}{c}\mathrm{CO}_{2} \text { Emission } \\
(\mathrm{Kg}) \text { per year }\end{array}$ & 4102.38 & 4067.96 & 4067.85 & 4126.08 & 4065.84 \\
\hline $\begin{array}{c}\text { Ave. } \\
\text { WWR }\end{array}$ & $\begin{array}{c}\mathrm{CO}_{2} \text { Emission } \\
(\mathrm{Kg}) \text { per year }\end{array}$ & 4000.92 & 3985.46 & 3982.78 & 3973.41 & 3961.43 \\
\hline $\begin{array}{c}\text { Stand. } \\
\text { WWR }\end{array}$ & $\begin{array}{c}\mathrm{CO}_{2} \text { Emission } \\
(\mathrm{Kg}) \text { per year }\end{array}$ & 3940.55 & 3934.28 & 3933.32 & 3969.49 & 395.26 \\
\hline
\end{tabular}

Table 4. The simulation results of carbon dioxide emission in inner-land region (sea view and Mountain View). (Developed by researchers)

\begin{tabular}{|c|c|c|c|c|c|c|c|}
\hline \multicolumn{5}{|c|}{ North (Sea View) } & \multicolumn{3}{|c|}{ South (Mountains View) } \\
\hline \multicolumn{2}{|c|}{ Inner-land } & $\begin{array}{c}\text { Double clear } \\
3 \mathrm{~mm} / 6 \mathrm{~mm} \\
\text { Air glass }\end{array}$ & $\begin{array}{c}\text { Double Grey } \\
3 \mathrm{~mm} / 6 \mathrm{~mm} \text { Air } \\
\text { glass }\end{array}$ & $\begin{array}{c}\text { Triple Clear } \\
3 \mathrm{~mm} / 6 \mathrm{~mm} \\
\text { Air glass }\end{array}$ & $\begin{array}{c}\text { Double clear } \\
3 \mathrm{~mm} / 6 \mathrm{~mm} \\
\text { Air glass }\end{array}$ & $\begin{array}{c}\text { Double Grey } \\
3 \mathrm{~mm} / 6 \mathrm{~mm} \\
\text { Air glass }\end{array}$ & $\begin{array}{c}\text { Triple Clear } \\
3 \mathrm{~mm} / 6 \mathrm{~mm} \\
\text { Air glass }\end{array}$ \\
\hline $\begin{array}{c}\text { Maximum } \\
\text { WWR }\end{array}$ & $\begin{array}{l}\mathrm{CO}_{2} \text { Emission } \\
(\mathrm{Kg}) \text { per year }\end{array}$ & 4102.45 & 4067.89 & 4067.91 & 4125.99 & 4065.75 & 4066.56 \\
\hline $\begin{array}{c}\text { Average } \\
\text { WWR }\end{array}$ & $\begin{array}{l}\mathrm{CO}_{2} \text { Emission } \\
(\mathrm{Kg}) \text { per year }\end{array}$ & 4000.92 & 3984.95 & 3982.81 & 3973.30 & 3961.49 & 3955.20 \\
\hline $\begin{array}{l}\text { Standard } \\
\text { WWR }\end{array}$ & $\begin{array}{l}\mathrm{CO}_{2} \text { Emission } \\
(\mathrm{Kg}) \text { per year }\end{array}$ & 3940.53 & 3934.27 & 3933.09 & 3969.60 & 3959.53 & 3952.43 \\
\hline
\end{tabular}

\subsection{Inner-Land Area}

The inner- land region in this paper refers to the urban fabric of the city that contains the city with its various neighborhoods adjacent to coastal area until the starting of the mountainous region. In this paper, the average height of this area is 60 meters. The simulated model in DB software showed that the end results of the buildings placed in the inner- land are analogous to those in the coastal areas, and that the differences are slight. See Table ' 5 '.

The cause of achieving analogous results for both the inland and coastal regions depends on the following points: The same external temperature for both regions, given that the two regions are neighbouring and have similar climatic characteristics and share similar solar radiation. It should be noted that during the simulation in $\mathrm{DB}$, ventilation and thermal bridges were not taken into account. A limit of this study is that it focuses on the effect of window type, size on energy consumption and $\mathrm{CO}_{2}$ emissions in selected case study buildings in the Kyrenia region.

\subsection{Mountainous Settlement (Karmi Village)}

Karmi village is a mountain settlement placed in the Kyrenia mountain range overlooking the Kyrenia region. The village is about 300 meters high. Due to the difference in land elevation, the temperature is usually 1 to $1.5^{\circ} \mathrm{C}$ lower than the coastal and inner-land regions. There is difference between the village of Karmi and Kyrenia other regions by almost 200 meter, and according to Givoni, and Reinhold, [31], they asserted that 100 meters raise in land elevation make the temperature drop by about $0.8^{\circ} \mathrm{C}$. Sea view buildings and buildings with mountain views were simulated in DB software and the results are as follows. The chosen case studies placed in the mountainous settlement which are overlooking the sea typically produce the highest $\mathrm{CO}_{2}$ emissions annually, which is the opposite of other areas (coastal or inland). The exception of this is only when WWR meets the standard, as shown in Table ' 6 '. However, the maximum WWR is the reason for more production of $\mathrm{CO}_{2}$ as per the simulation results. It should be mentioned that commonly, the mountainous region produces lower carbon footprint than other regions. The main reason for the decrease in the total amount of carbon emissions in residential buildings in Karmi village is s goes back to the fact that the average temperature in Karmi village is less than in the coastal and inland areas. The best type glass that can be applied in buildings with a maximum WWR is triple clear glass. This type of glass will reduce the total $\mathrm{CO}_{2}$ emissions. Also, triple clear glass can be provided for buildings of standard and average WWR because of the low heat transfer coefficient vale (U-value) of this type of glazing. South-facing buildings (Mountain View) receive the maximum direct sunlight in this area, which leads to the heating of the building interior design based on the principle of passive heating. Simulation results show that when WWR increases from average to maximum, the total amount of $\mathrm{CO}_{2}$ emissions increases to $104 \mathrm{~kg}$ (per 100 square meters of residential buildings). However, in the case study buildings placed in the Karmi village, when WWR raises from standard to average, DB simulation findings show negligible differences in $\mathrm{CO}_{2}$ emission. Also, the same point is valid for the selected case study buildings located in the coastal zone and interior land area. 
Table 5. The DB simulation results for buildings located in mountainous region (sea view and mountains view). (Developed by researchers).

\begin{tabular}{|c|c|c|c|c|c|c|c|}
\hline \multicolumn{4}{|c|}{ North (Sea View) } & \multicolumn{3}{c|}{ South (Mountains View) } \\
\hline \multicolumn{2}{|c|}{ Mountains } & $\begin{array}{c}\text { Double clear } \\
3 \mathrm{~mm} / 6 \mathrm{~mm} \\
\text { Air }\end{array}$ & $\begin{array}{c}\text { Double Grey } \\
3 \mathrm{~mm} / 6 \mathrm{~mm} \\
\text { Air }\end{array}$ & $\begin{array}{c}\text { Triple Clear } \\
3 \mathrm{~mm} / 6 \mathrm{~mm} \\
\text { Air }\end{array}$ & $\begin{array}{c}\text { Double clear } \\
3 \mathrm{~mm} / 6 \mathrm{~mm} \\
\text { Air }\end{array}$ & $\begin{array}{c}\text { Double Grey } \\
3 \mathrm{~mm} / 6 \mathrm{~mm} \\
\text { Air }\end{array}$ & $\begin{array}{c}\text { Triple Clear } \\
3 \mathrm{~mm} / 6 \mathrm{~mm} \\
\text { Air }\end{array}$ \\
\hline $\begin{array}{c}\text { Maximum } \\
\text { WWR }\end{array}$ & $\begin{array}{c}\mathrm{CO}_{2} \text { Emission } \\
(\mathrm{Kg} \text { ) per year }\end{array}$ & 4056.67 & 4024.95 & 4022.21 & 4052.14 & 4004.02 & 3999.19 \\
\hline $\begin{array}{c}\text { Average } \\
\text { WWR }\end{array}$ & $\begin{array}{c}\mathrm{CO}_{2} \text { Emission } \\
\left(\mathrm{Kg}_{\text {g per year }}\right.\end{array}$ & 3968.29 & 3954.17 & 3941.07 & 3924.58 & 3914.76 & 3906.27 \\
\hline $\begin{array}{c}\text { Standard } \\
\text { WWR }\end{array}$ & $\begin{array}{c}\mathrm{CO}_{2} \text { Emission } \\
(\mathrm{Kg}) \text { per year }\end{array}$ & 3906.13 & 3900.01 & 3898.09 & 3922.47 & 3913.86 & 3904.33 \\
\hline
\end{tabular}

The study confirmed on the very effective role for aperture size change on $\mathrm{CO}_{2}$ mitigation emissions. According to the simulation results, more WWR leads to higher carbon dioxide emissions in residential buildings in Kyrenia. An extrapolation of the findings indicates that $\mathrm{CO}_{2}$ emissions in sea-view buildings are higher than those in mountains view ones in coastal and inner-land regions. On the other hand, emissions in mountainous areas or higher topographic levels are opposite, where, in this region, emissions indicated for sea-view scenarios are higher than emissions for mountains view, except with standard WWR values. Furthermore, the results showed that there are differences in the emission value for different topographic regions in Kyrenia, when we consider the same WWR values. The simulation results confirmed that the mountainous region has less carbon dioxide emissions compared to other regions (inner-lands and coastal). Furthermore, the results demonstrated that there are not remarkable differences in carbon dioxide emissions between the coastal and inner-land regions. WWR for the buildings with "sea view" 1 can be larger in mountain settlement than ones in coastal and inland areas, making up $33 \%$ difference in $\mathrm{CO}_{2}$ emissions. Moreover, buildings in these mountainous regions can have 35\% more bigger WWR with maintaining similar $\mathrm{CO}_{2}$ emissions compared to analogous buildings in the inner-land and coastal region.

\subsection{The Relationship between WWR Value and $\mathrm{CO}_{2}$ Emission in the Residential Buildings}

To understand the relationship between $\mathrm{CO}_{2}$ emissions and glass size in residential buildings through the scale of (WWR) in three regions of Kyrenia with the respect of the concerned orientations (sea and mountains view) a linear regression analysis has conducted. It is important to note that there is relationship between the annual amount of $\mathrm{CO}_{2}$ emissions generated and the increase or decrease in the value of WWR in the present case study buildings in the Kyrenia region. The total amount of carbon dioxide emissions was taken into account for both orientations in buildings, the northern (sea view) and southern (Mountain View). Different values of WWR (maximum, standards, and average) were applied for the average emission of the three types of glazing materials that have applied as the most prevailed materials in the study region. A "correlation coefficient-R2", in addition to the line formula were found for each topographic region (coastal, inner-land, mountainous) for sample of buildings that oriented to the sea view and mountain's view.

The results showed that there is a very strong correlation coefficient (R2), which is equal to (0.9995) for buildings overlooking the sea, and (1) for buildings overlooking the mountains. There is a similar result with almost negligible differences in the linear regression analysis during the comparison between the buildings located in the coastal region with the ones placed in the inner-land area. The correlation coefficient (r2) for both buildings facing north (sea view) and south (Mountain View) have found 0.9995 and 1 , respectively.

The linear regression of the mountainous region (Karmi) showed differences compared to other two regions in Kyrenia region (coastal inner- land and coastal areas). The correlation coefficient was very strong (1) for buildings overlooking the sea (facing north) and (0.9999) for buildings overlooking the mountains (facing south). The following formulas are mathematical models of linkage between (WWR) and annual $\mathrm{CO}_{2}$ emissions within residential buildings identified for the case study with a sea view (north direction) and mountain view (south direction) in three different topographic regions of the Kyrenia region. See Table ' 7 '.

The result of the proposed models shows that there are no statistically significant differences in the relationship between the WWR values and the annual $\mathrm{CO}_{2}$ emission for each of the selected case study buildings located in the coastal area and the inner land area. However, the models illustrate the differences in the correlation between the WWR values and the amount of $\mathrm{CO}_{2}$ emissions for samples of the building located in the mountainous region at Karmi compared to the coastal and inner land regions. The analyses for the different topographic regions have approached according to average the total annual $\mathrm{CO}_{2}$ emissions in each region. 
Table 6. The mathematical models correlating $\mathrm{CO}_{2}$ emissions through WWR in the residential buildings of Kyrenia (Developed by Researchers)

\begin{tabular}{|c|c|c|c|}
\hline Location & Orientation & Mathematical Model & $\begin{array}{c}\text { Correlation } \\
\text { Coefficient }\end{array}$ \\
\hline \multirow{2}{*}{ Coastal Area } & Sea View & $\mathrm{CO}_{2}$ Emission=235.62(WWR)+3894.90 & $\mathrm{R}^{2}=0.9995$ \\
\cline { 2 - 4 } & Mountain View & $\mathrm{CO}_{2}$ Emission $=322.67(\mathrm{WWR})+3860.30$ & $\mathrm{R}^{2}=1$ \\
\hline \multirow{2}{*}{ Inner-Land Area } & & & $\mathrm{R}^{2}=0.9995$ \\
\cline { 2 - 4 } & Sea View & $\mathrm{CO}_{2}$ Emission $=235.82(\mathrm{WWR})+3894.70$ & $\mathrm{R}^{2}=1$ \\
\hline \multirow{2}{*}{ Mountainous Area } & Sea View & $\mathrm{CO}_{2}$ Emission $=322.51(\mathrm{WWR})+3860.30$ & $\mathrm{R}^{2}=1$ \\
\cline { 2 - 4 } & Mountain View & $\mathrm{CO}_{2}$ Emission $=218.20(\mathrm{WWR})+3864.60$ & $\mathrm{R}^{2}=0.9999$ \\
\hline
\end{tabular}

The selected building samples in a mountain settlement produce the lowest amount of $\mathrm{CO}_{2}$ per year (though sample buildings that chosen in three regions have similar WWR and glass materials). The WWR were calculated for the selected case study buildings located in the coastal region, inner-land region overlooking the sea (northward) and mountainous landscape (southward). The results demonstrated that those both regions produce a similar amount of annual $\mathrm{CO}_{2}$ emissions compared to case study buildings placed in mountainous region. This is achieved by balancing the annual emission of carbon dioxide (Y) value in the model formulas of the selected residential buildings situated in a mountain community with a sea view and mountains view $(\mathrm{X})$, which is the WWR value. New (X) values would then be obtained, taking into account the new value of the WWR for coastal and inner-land areas. Therefore, the simulation model results suggest that the WWR must be decreased by 33 percent in order to minimize the total emission of Carbon dioxide in the selected residential buildings located in the coastal region and the inner land regions that overlooking the sea. The 33\% reduction in WWR for buildings placed in the coastal region and inner- land region oriented to the seaward will produce similar annual emissions of $\mathrm{CO}_{2}$ with buildings placed in the mountainous area oriented to the seaward too. It should be mentioned that it is necessary to make a 35\% reduction in WWR for buildings located in the coastal region and the inner land region overlooking the mountains to produce similar annual emissions of $\mathrm{CO}_{2}$ to buildings located in the mountainous region (Karmi) overlooking the mountains.

\section{Conclusion}

The paper examined the relationship between building aperture and carbon dioxide emissions based on the role of aperture on the buildings carbon emission in Kyrenia in North Cyprus. The study showed that there is high energy consumption and $\mathrm{CO}_{2}$ emissions to maintain comfort in the residential buildings in Kyrenia (thermal performance and optical performance). Residential buildings in North Cyprus share around $30 \%$ of the island's total energy consumption [32]. The paper confirmed the existence of an efficient function for aperture to adjust carbon dioxide emission. As per the results of the simulation, the higher the WWR, the greater the rise in $\mathrm{CO}_{2}$ emissions in residential buildings in Kyrenia. The analysis of the findings shows that carbon dioxide emission is bigger in the sea -view than in the mountains view in coastal and inner-land region, while it was opposite in the mountainous region, for both maximum and average WWR. However, by applying standards WWR in the mountainous region will be similar to coastal and inner-land regions. Moreover, the results demonstrated that there is variety in the emission amount for different regions in case study area (Kyrenia) when the same WWR values are considered. The DB simulation results have proved that the mountainous region has less carbon dioxide emissions in comparison to other regions (coastal and inner-land). No significant differences in $\mathrm{CO}_{2}$ emissions between the coastal and inner-land area were found. In higher lands than the homonymous ones in coastal and inland areas, 'sea view' buildings can have a greater WWR, achieving up to $33 \%$ difference in $\mathrm{CO}_{2}$ emission in similar conditions. Also, as opposed to similar buildings in coastal and inner-land regions, buildings in the mountains area with "mountain view" may still have a greater WWR by 35 percent with the same $\mathrm{CO}_{2}$ emission. Based on the results of the current study, it was substantial to explore a method for architects and designers to be able to assess $\mathrm{CO}_{2}$ emissions in residential buildings in Kyrenia. In particular, when carbon dioxide emissions values differ between various regions (coastal, inner-land, and mountains), and between buildings with a sea view and buildings with a mountain view. The study, therefore, indicates a linear relationship, with linear regression equations applied between WWR and $\mathrm{CO}_{2}$ emissions in each region with distinct views. The study findings developed mathematical models to measure $\mathrm{CO}_{2}$ emissions based on the value of the WWR, with differences in regions and building orientations. 


\section{Acknowledgements}

This research did not receive any specific grant from funding agencies in the public, commercial, or not-for-profit sectors.

\section{Conflict of Interests}

The Authors declare no conflict of interest.

\section{REFERENCES}

[1] Abdallah L., El-Shennawy T, "Reducing Carbon Dioxide Emissions from Electricity Sector Using Smart Electric Grid Applications," Journal of Engineering, vol. 1, no. 8, 2013. Doi:10.1155/2013/845051

[2] Iranfar M., Muhy Al-din S.S, "The Cognition of the Architectural Styles Role on Thermal Performance in Houses of Semi-Arid Climates: Analysis of Building Envelope Materials," Civil Engineering and Architecture, vol. 8, no. 5, pp. 929-941, 2020. DOI: 10.13189/cea.2020.080520

[3] Yang L., Yan H., Lam J. C, "Thermal comfort and building energy consumption implications - A review," Applied Energy, 115, pp. 164-173, 2014. DOI: 10.1016/j.apenergy.2013.10.062

[4] Pacala S., Socolow R., "Stabilization wedges: Solving the climate problem for the next 50 years with current technologies," Science, 305, pp. 968-972, 2004. DOI: $10.1126 /$ science. 1100103

[5] Daminabo F.O, Obagha R., "Zero Carbon Architecture and Renewable Energy Technologies; a Periscope.” Journal of Sciences and Multidisciplinary Research, vol. 10, no. 1, pp. 81-94, 2018.

[6] Muhy Al-Din S. S., Iranfare M., Surch Z. N. S, "Building Thermal Comfort Based on Envelope Development: Criteria for selecting right case study in Kyrenia- North Cyprus," Energy Procedia, 115, pp. 80-91, 2017. Doi: 10.1016/j.egypro.2017.05.009

[7] Smiciklas J., de Jager L., Cucchietti F., Zeddam A., Manuel Canet J., Scheidt L.G., Herrmann C., Mazzone G., Wood D., Smith R., Chauhan Y., Ali M., Parikh R., Purushottam S., Bhowmick S. K., A. West S., De Furia N., T. Lloyd C., Ziegler S, "Go Green: Sustainable buildings," IT, https://www.itu.int/dms_pub/itu-t/oth/4B/04/T4B0400000 B0012PDFE.pdf

[8] Al-Homoud M., Degelman L., Boyer L, "The Framework of an Optimization Model for the Thermal Design of Building Envelopes," The Ninth Symposium on Improving Building Systems in Hot and Humid Climates, Arlington, TX, USA, January.,1994,pp.100-109.

[9] Urbikain M.K., Sala J.M, “Analysis of Different Models to Estimate Energy Savings Related to Windows in Residential Buildings," Energy and Buildings, vol.41, no. 6, pp. 687-695, 2009.
[10] Hübe H, "Energy-Efficient Window Systems - Effects on Energy Use and Daylight in Buildings," $\mathrm{PhD}$ thesis, Division of Energy and Building Design, Department of Construction and Architecture, Lund University, Sweden, 2001.

[11] Guattari F, “The Three Ecologies," Athlone Press, 2005, pp. 23-69.

[12] Collins B. L, "Review of the psychological reactions to windows," Lighting Research \& Technology, vol. 8, no. 2, pp. 80-88, 1976.

[13] Rusak B, Eskes G. A., Shaw, S. R, "Lighting and Human Health: a Review of the Literature," Mortgage and Housing Corporation, https://www.osti.gov/etdeweb/biblio/394505 (accessed Jan. 1, 2019).

[14] Heerwagen J., Wener R, "Windows, windowlessness and simulated view," Environmental Design Research Association, pp. 269-280, 1990.

[15] Givoni B, "Climate considerations in building and urban design," 1998.

[16] Fesharaki M. H., "Energy optimisation in Residential Apartments through the Passive Design Strategies by Evaluating the Local Construction Materials and Designs in Semi-Arid Climate Condition of Tehran", Manchester: University of Salford,2018.

[17] Atmaca A, "Carbon Footprint Analysis of a Residential Building," UEMK Gaziantep University", Gaziantep, Turkey, December, 2019, pp. 866- 879.

[18] Lucon O., Ürge-Vorsatz D., "Climate Change 2014 Mitigation of Climate Change." Edenhofer R., Pichs-Madruga Y., Sokona, E. Farahani, S. Kadner, K. Seyboth, A. Adler..., J.C. Minx (eds.), Climate Change 2014: Mitigation of Climate Change, Cambridge University Press, USA, New York, pp. 671-738,2014.

[19] Basarir B., Diri B. S., Diri C, "Energy efficient retrofit methods at the building envelopes of the school buildings," PhD thesis, Department of Architecture, Mimar Sinan Fine Arts University, Turkey, 2012.

[20] Casini M, "Smart windows for energy efficiency of buildings," Conf. on Advances in Civil, Structural and Environmental Engineering- ACSEE, 2014. Doi: 10.15224/ 978-1-63248-030-9-56

[21] Lapithis P. A, "PASSIVE SOLAR ARCHITECTURE IN CYPRUS,"

https://www.researchgate.net/publication/259974261_PAS SIVE_SOLAR_ARCHITECTURE_IN_CYPRUS (accessed March. 29, 2019).

[22] Ahmed A., Khalid A., Ahmed B., Mohsin S., "Impact of Solar Radiation on Building Envelope Using Energyplus Software," SIMEC, Karachi, Pakistan, March., 2017, pp. 24-25.

[23] Takebayashi H., Kasahara M., Tanabe S., Kouyama M, "Analysis of Solar Radiation Shading Effects by Trees in the Open Space around Buildings," Sustainability, vol.9, no. 8, pp. 2-9, 1398. DOI: $10.3390 /$ su9081398

[24] Florides G.A., Kalogiroua S.A., Tassou S.A, Wrobel L.C, "Modeling of the modern houses of Cyprus and energy consumption analysis," Energy, vol. 25, no. 10, pp. 915937, 2000. 
[25] Yaşar Y., Kalfa S. M, "The effects of window alternatives on energy efficiency and building economy in high-rise residential buildings in moderate to humid climates," Energy Conversion and Management, 64, pp. 170-181. DOI: 10.1016/j.enconman.2012.05.023

[26] Roos A., Karlsson B, "Optical and thermal characterization of multiple glazed windows with low U-values," Solar Energy, vol. 52, no. 4, pp. 315-325, 1994. Doi: 10.1016/0038-092x (94)901384.

[27] Adhikari P., Bhattarai R.N., "A Review of Glazing Materials and its Prospects in Buildings of Kathmandu Valley," U International Conference on Technology and Innovation Management \& IOE Graduate Conference, Kathmandu, Nepal, October, 2014,pp.279-288.

[28] Ding, G., Clavero, C., Schweigert, D., \& Le, M. (2015). Thickness and microstructure effects in the optical and electrical properties of silver thin films. AIP Advances, 5(11). doi:10.1063/1.4936637
[29] Design Builder 2.1 User's Manual, "Design Builder Software."2009, http://www.designbuildersoftware.com/docs/DesignBuilde r_2.1_Users-Manual_Ltr.pdf (accessed June. 30, 2020).

[30] Wasilowski H. A., Reinhart C. F., "Modelling an existing building in design builder/energy plus: Custom versus default inputs," Building simulation, Eleventh International IBPSA Conference, Glasgow, Scotland, July., 2009, pp. 1252-1259.

[31] Givoni, B., Reinhold, V.N. (1994). Passive and Low Energy Cooling of Building. United State of America: John Wiley \& Sons, INC.

[32] Kamali S, "Improving Thermal Comfort in Building and Reducing the Indoor Air Temperature Fluctuation in Cyprus by Utilizing the Phase Change Materials,"2014, http://i-rep.emu.edu.tr:8080/jspui/bitstream/11129/1713/1/ KamaliSaeed.pdf (accessed March 15,2020). 